\title{
Residual Behavior of Malathion and its Metabolite Malaoxon in Four Varieties of Mango Fruits
}

\author{
Sanaa A.M. El-Sawi \\ Central Lab. for Analysis of Pesticide Residues and Heavy Metals in Foods, \\ Agricultural Research Center, Dokki, Giza, Egypt
}

\begin{abstract}
The degradation rates and residue levels of malathion as an insecticide and its metabolite malaoxon were studied on field grown four varieties of mango trees (Alfouns, Zebdia, Fajeri Klan, and Langra). The samples were collected after one hour, 1, 3, 5 , and 7 days post insecticide application. The data showed that the recovery rates of QUCHER method were satisfied for both malathion and malaoxon. The obtained rates of recovery were 97 and $99 \%$ for malathion and malaoxon, respectively. The obtained residues of both compounds under investigation (malathion and malaoxon) decreased gradually with time, whereas, and there were no residues found 5 days later for malathion. Also, malaoxon showed the same pattern of degradation thus it disappeared after 3 days from treatment. The half-life time values of malathion $\left(\mathrm{LT}_{50}\right)$ ranged from 0.96 to 2.8 days in these four mango varieties while they were ranged between 0.43 to 0.9 days for malaoxon. The pre-harvest interval (PHI) for each compound was determined according to their maximum residue limits which were 3 and 2 days for malathion and malaoxon, respectively on all four varieties of mango fruits.
\end{abstract}

Key words: $\mathrm{PHI}$, malathion, malaoxon residues, mango

\section{INTRODUCTION}

Mango (Mangiferae indica) is one of the finest fruits and the most important fruit crops in tropical and subtropical areas of the world. Increasing commercial acreage and improved handling methods and shipping throughout the world have increased the mango's popularity and availability in Europe and US markets. Over the years, mango groves have spread to many parts of the tropical and sub-tropical world, where the climate allows the mango to grow best, and where most of the developing countries located. To date, developing countries are facing massive economic and social problems. One possible way out of this misery seems to be the opening of the economy in order to participate in the gains arising from international trade. By increasing export volume and export revenues, developing countries expect to create a momentum and, thus, the impetus to stimulate the overall economy (Borchert, 2001).

Since Egypt located at mango production area, it is a big chance to share in the international mango market by improving mango production quantity and quality.

Mango suffers from several diseases at all stages of its life. All the parts of the plant, namely, trunk, branches, twigs, leaf, petiole, flower and fruit are attacked by a number of pests including insects. They cause huge damage in quality and production of mango fruits (Ploetz, 2004 and Kaiser and Saha, 2005).

Malathion, is a non-systemic insecticide. This insecticide is cholinesterase enzyme inhibitor. Malathion can be bioactivated to malaoxon via oxidation desulfuration by insect metabolism and then is transformed to 
isomalathion by thermal or photochemical isomerization. Isomalathion has been identified in certain commercial formulations and is suspected to be a prime agent in the death of 5 workers and the sickening of another 2800 in Pakistan during a 1976 malaria-eradication program (Anping et al., 2013). Malathion and malaoxon contain an asymmetric carbon atom, which leads to the formation of two enantiomers, respectively. The isomerization of malathion to isomalathion not only maintains the asymmetric carbon atom but also forms a new asymmetric phosphorus atom, yielding four possible stereoisomers ( $\mathrm{Yu}$ et al., 2010). At present, malathion is still marketed and applied in its racemic form despite the fact that the (R)-enantiomer shows a higher biological activity than the (S)-isomer (Anping et al., 2013).

Malathion is effective in controlling many insects such as leaf eating caterpillars, thrips, cockchafer larvae, cutworms, etc. in a range of crops including vegetables, fruits, maize, sugar cane, sugar beet, tea, tobacco, and ornamentals. However, malathion has, however, been reported to have endocrine disrupting effects, Penalve et al. (2003). Malathion may have harmful effects on large numbers of people are exposed to malathion in their home or work environment, or through consumption of foods containing trace levels of OP insecticides (Barr, 2004). Therefore, the environmental behavior of malathion is increasingly being investigated.

This study is aiming to throw the light upon the residues of malathion and its metabolite malaoxon on most famous mango varieties in Egypt as well as the residues amount in the fruit with special reference to pre-harvest interval $(\mathrm{PHI})$.

\section{MATERIAL AND METHODS}

This study was carried out during 2011 and 2012 seasons on four different mango varieties namely Alfouns, Zebdia, , Fajeri Klan , and Langra (10 years old trees) grown in Elkatatba (Menoufia governorate).

\section{Tested Pesticide:}

Malathion was used as malatox $57 \%$ EC at the recommended dose (30 $\mathrm{ml} /$ liter of water) to control pests attacking mango trees. Malathion was sprayed for one time.

a- Malathion diethy[(dimethoxythiophosphinothioyl)thio]butanedioate

b- Malaoxon (O- [1,2-bis(ethoxycarbonyl)ethyl] O,O-dimethyl phosphorodithioate)<smiles>CCOC[C@@H](CC(=O)OCC)SP(=S)(OC)OC</smiles>

a Malathion<smiles>CCOCC(C)(CSP(=O)(OC)OC)OCC</smiles>

b Malaoxon

Fig 1: Chemical structure of malathion (a) and its isomer malaoxon (b) 


\section{Sampling}

Fruit samples of each mango variety were randomly picked up after one hour, $1,3,5$ and 7 days after treatment.

\section{Extraction:}

The procedure of Lehotay et al. (2005) as a QuCHER (Quick, Cheap, Effective and Rugged) method was used for extraction and purification of pesticide residues from mango samples. The analysis procedure was done at the Central Lab. of Residue Analysis of Pesticides and Heavy Metals in Food, Agric. Res. Center, Egyptian Ministry of Agriculture. Fresh sample of $10 \mathrm{~g}$ was weighed and mixed with $10 \mathrm{ml}$ deionized water in a $50 \mathrm{ml}$ PFTE tube by shaking for one minute. Acetonitrile acidified with acetic acid $(10 \mathrm{ml}), 1.0 \mathrm{~g}$ sodium acetate and $4.0 \mathrm{~g}$ anhydrous magnesium sulphate were added and shaked vigorously for one minute. The samples were centrifuged at $4000 \mathrm{rcf}$ for $2 \mathrm{~min}$. Six milliliters of the upper clear solution (extracts) were transferred into $15 \mathrm{ml}$ polyethylene tube contained $0.4 \mathrm{~g}$ primary secondary amine (PSA) sorbent and $0.6 \mathrm{~g}$ anhydrous magnesium sulphate. The tubes were caped, then the extract with the sorbent/ dessicant mixed vigorously for one minute and centrifuged at 4000 rcf for 2 min. Four milliliters of the clear solution were transferred into $15 \mathrm{ml}$ glass tube and $50 \mu \mathrm{l}$ tetradecan was added as keeper and evaporated in turbovab at $40{ }^{\circ} \mathrm{C}$ to dryness. The residues were dissolved in $2 \mathrm{ml}$ of acetonitrile and then injected in $\mathrm{GC}$.

For recovery studies, the samples were spiked with the studied compounds before the corresponding extraction procedure has been done. $A$ representative $10 \mathrm{~g}$ portion of mango sample was weighed and fortified homogeneously with appropriate volume of working standard solution and followed the same previous procedure of determination.

Spiked levels were $0.03,0.1$ and $1.0 \mathrm{mg} / \mathrm{kg}$. The obtained results were corrected according to the recovery rate.

\section{GLC procedures:}

Assessment of malathion and malaoxon residues was carried out according to the Official Methods of Analysis (Anonymous, 1995) using Hewlett Packard gas liquid chromatography (HP 6890N) equipped with nitrogen phosphorus detector (NPD), two columns, (HP PAS-5, NPD tested Ultra 2 Silicone, $0.32 \mathrm{~mm}$ i.d., $0.52 \mu \mathrm{m}$ film thickness and $25.0 \mathrm{~m}$ length and HP PAS-1701, $0.32 \mu \mathrm{m}$ i.d., $0.25 \mu \mathrm{m}$ film thickness and $25 \mathrm{~m}$ length), HP autosampler and HP computer under the following operating conditions:

Injector temperature $=225{ }^{\circ} \mathrm{C}$, Detector temperature $=280{ }^{\circ} \mathrm{C}$, Flow rate of nitrogen $60 \mathrm{ml} / \mathrm{min}$ (carrier + makeup), Column head pressure $80 \mathrm{kPa}$, Splitless time $0.7 \mathrm{~min}$.

The oven was programmed as follow:

Initial oven temperature: $90^{\circ} \mathrm{C}$, Initial oven time 2 min. using two ramps, Ramp (1) Rate $20^{\circ} \mathrm{C} / \mathrm{min}, \operatorname{Temp} 150^{\circ} \mathrm{C}$, Time $0 \mathrm{~min}$. and

Ramp (2) Rate $6^{\circ} \mathrm{C} / \mathrm{min}$, Temp $270{ }^{\circ} \mathrm{C}$ Time $15 \mathrm{~min}$. 
The determined concentration in sample (Cs) $(\mathrm{mg} / \mathrm{kg}$ ) was calculated as follows:

$$
C s=\stackrel{\text { As } / \text { Ais }}{ } \times \text { Cst } \times \text { Vf } \times \text { Vtot }
$$

Ast / Aist Va $\quad$ M

Where:

As $=$ Peak area of analyte in sample

Ais $=$ Peak area of ditalimiphos standard in sample

Ast $=$ Peak area of analyte in standard run

Aist $=$ Peak area of ditalimiphos standard in standard run

Cst $=$ Concentration of standard $(\mathrm{mg} / \mathrm{L})$

$\mathrm{Vf}=$ Final volume $(\mathrm{ml})$

Vtot. $=$ Total extraction volume $(\mathrm{ml})$

$\mathrm{Va}=40 \mathrm{ml}$

$\mathrm{M}=$ Sample weight in final volume $(\mathrm{g})$

Half life time $\left(\mathrm{LT}_{50}\right)$ was calculated and pre-harvest interval $(\mathrm{PHI})$ was determined considering the MRL for malathion and its metabolite malaoxon on mango which equal 0.2 and $0.05 \mathrm{mg} / \mathrm{kg}$, respectively according to Annex II Regulation of European Union (Anonymous, 2005).

\section{RESULTS AND DISCUSSION}

Pesticides residues in food stuff are one of the most limiting factors affect the trade and export of all edible products. The objective of the present investigation was monitoring the residues of malathion and its metabolite malaoxon in four varieties of mango fruits through a period of time, and predicting their PHI (Pre Harvest Interval). Since MRL (Maximum Residue Limit) of malathion is $0.2 \mathrm{mg} / \mathrm{kg}$, The estimated PHI (Pre Harvest Interval) was found to be 3days. For malaoxon, MRL is $0.05 \mathrm{ppm}$ and therefore, the estimated $\mathrm{PHI}$ was found to be 2 days and the calculated $L T_{50}$ values of malation ranged from 0.96 to 2.8 days in these four varieties however, for malaoxon it was ranged between 0.43 to 0.9 days (Table 1). These results are in agreement with those reported by Lotfy et al. (2013) who found that $\mathrm{LT}_{50}$ on zucchini was around 0.77 days and PHI was 0.5 days. 
Table 1. Malathion and malaoxon residues, dissipation \% in different mango varieties fruit after different intervals from treatment, half life time $\left(\mathrm{LT}_{50}\right)$, and pre-harvest interval $(\mathrm{PHI})$

\begin{tabular}{|c|c|c|c|c|c|c|c|c|}
\hline \multirow{3}{*}{$\begin{array}{l}\text { Time } \\
\text { Post- } \\
\text { application } \\
\text { (days) }\end{array}$} & \multicolumn{8}{|c|}{ Mango Types } \\
\hline & \multicolumn{2}{|c|}{ Al Founs } & \multicolumn{2}{|c|}{ Fager Kalan } & \multicolumn{2}{|c|}{ Langra } & \multicolumn{2}{|c|}{ Zebdia } \\
\hline & $\begin{array}{c}\text { Malathion } \\
(\mathrm{mg} / \mathrm{kg})\end{array}$ & $\begin{array}{c}\text { Malaoxn } \\
\text { (mg/kg }\end{array}$ & $\begin{array}{c}\text { Malathion } \\
(\mathrm{mg} / \mathrm{kg})\end{array}$ & $\begin{array}{c}\text { Malaoxn } \\
(\mathrm{mg} / \mathrm{kg})\end{array}$ & $\begin{array}{c}\text { Malathion } \\
\text { (mg/kg) }\end{array}$ & $\begin{array}{c}\text { Malaoxn } \\
\text { (mg/kg }\end{array}$ & $\begin{array}{c}\text { Malathion } \\
(\mathrm{mg} / \mathrm{kg})\end{array}$ & $\begin{array}{c}\text { Malaoxn } \\
(\mathrm{mg} / \mathrm{kg})\end{array}$ \\
\hline 0 & 0.49 & 0.15 & 2.3 & 0.35 & 1.7 & 0.13 & 0.87 & 0.18 \\
\hline 1 & 0.25 & 0.07 & 1.5 & 0.06 & 0.61 & 0.05 & 0.46 & 0.07 \\
\hline 3 & 0.13 & ND & 0.25 & ND & 0.1 & ND & 0.19 & ND \\
\hline 5 & 0.04 & ND & 0.08 & ND & 0.06 & ND & 0.02 & ND \\
\hline 7 & ND & ND & ND & ND & ND & ND & ND & ND \\
\hline $\mathrm{LT}_{50}$ & 2.8 & 0.9 & 1.6 & 0.55 & 0.96 & 0.43 & 1.1 & 0.85 \\
\hline PHI & 3 & 2 & 3 & 2 & 3 & 2 & 3 & 2 \\
\hline
\end{tabular}

$\mathrm{ND}=$ Not Detected, $\mathrm{LT}_{50}=$ Half Life Time

Malathion residues decreased with time and within every fixed time interval, the decrease is a constant ratio from the amount already present at the beginning of the interval, i.e., the rate of decrease in residues at any time is directly proportional to the amount of the residues at that time. Rapid disappearance of malathion and its metabolite malaoxon was observed in the studied varieties of Egyptian mango (Fig. 2 and 3), with no residue levels found after 5 days. These results are compatible with those of Mingjing et al., (2012). Control samples were fortified at the three levels of, $0.03,0.1$, and 1 , and average recovery percentages from spiked samples are listed in Table 2.

Table 2. Recovery percentage of malathion and malaoxon from mango at three fortification levels

\begin{tabular}{|c|c|c|c|c|c|c|}
\hline & \multicolumn{3}{|c|}{ Malation } & \multicolumn{3}{|c|}{ Malaoxon } \\
\hline $\begin{array}{l}\text { Fortification } \\
\text { level }\end{array}$ & $\begin{array}{l}0.03 \mathrm{ppm} \\
\mathrm{ppm}\end{array}$ & $0.1 \mathrm{ppm}$ & 1 & $\begin{array}{l}0.03 \mathrm{ppm} \\
\mathrm{ppm}\end{array}$ & $0.1 \mathrm{ppm}$ & 1 \\
\hline Recovery\% & $97^{88}$ & & 91 & $\begin{array}{l}85 \\
99\end{array}$ & & 90 \\
\hline
\end{tabular}

It is clear from Table 2 that the recovery ranged from 88 to $97 \%$ for malathion and 85 to $99 \%$ for malaoxon. The metabolites of malathion always were proved to be more toxic than the parent compound (Zhang et al., 2013). The higher toxicity of the metabolite is believed to be related higher bimolecular rate constants of malaoxon with acetylcholinesterase and carboxylesterase. Although malaoxon is a better inhibitor for carboxylesterase, malathion was proved to be the best stable substrate for this enzyme. In vivo, however, the inhibition reaction dominated the substrate reaction, resulting in the metabolites being more toxic (Hassan and Dauterman, 1968). So, it was important to determine the degradation rate and define the pre-harvest intervals of both insecticides. 


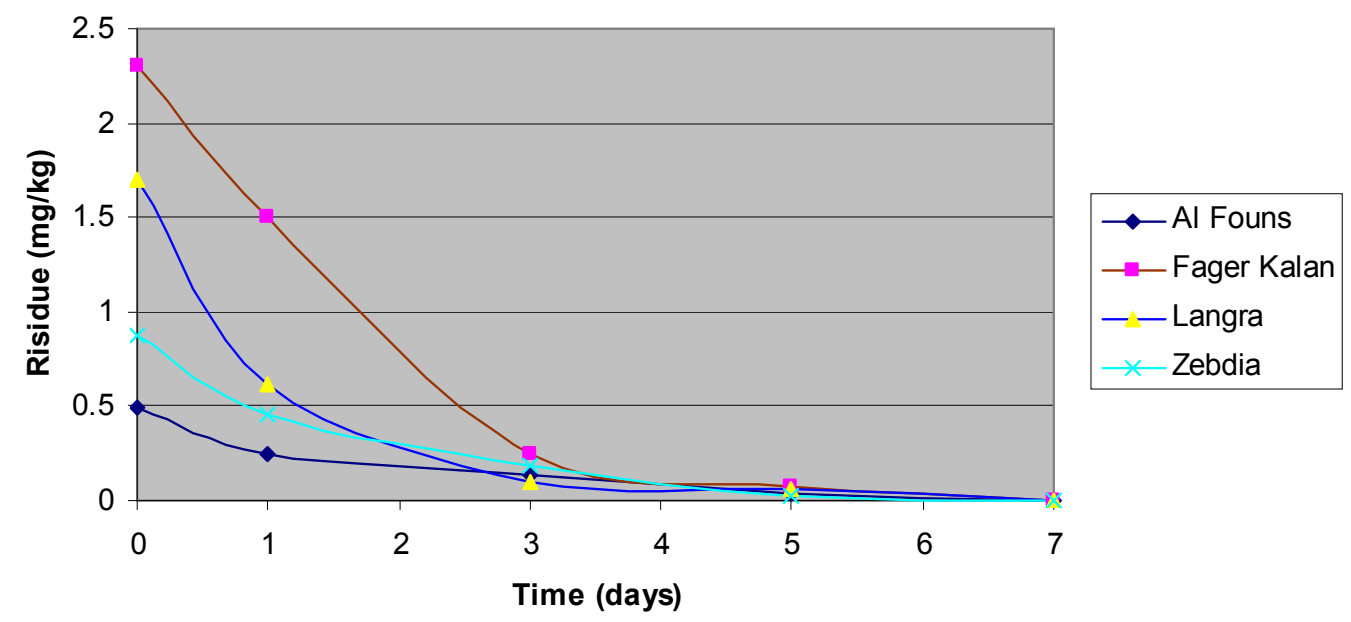

Fig 2: Decay of malathion residues in four mango varieties

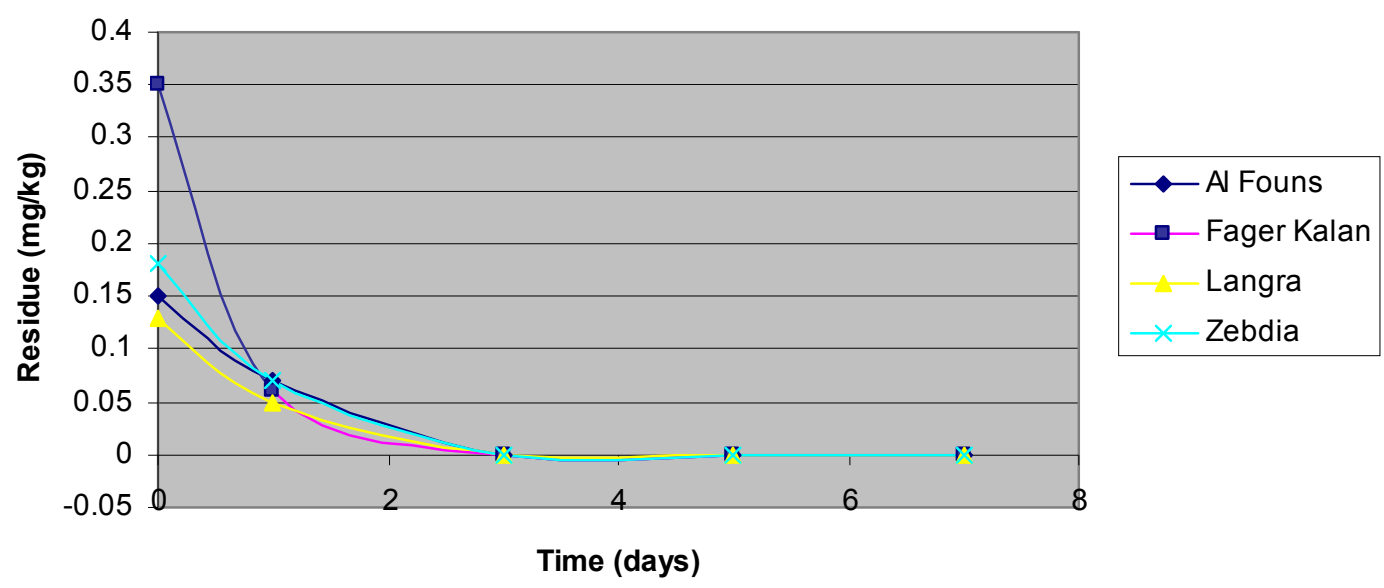

Fig 3: Decay of malaoxon residues in four mango varieties

\section{Recommendation}

The safety period for the harvesting of different varieties of mango fruits in Egypt should not before 3 days after treatment of the crop by malathion to avoid the adverse toxic effect of malathion on human health.

\section{REFERENCES}

Anonymous (1995). Official Methods of Analysis. 16th addition method 985.22. Association of Official Agricultural Chemists, INC. Suite 400. 2200 Wilson Boulvard. Arligton, Virginia 22201 USA

Anonymous (2005). Annex II to Regulation (EC) N. 396/2005 MRLs in the annexes to Council Directives 86/362/EEC, 86/363/EEC \& 90 /642/EEC. Official Journal of the European Union. 
Anping Z., L. Wenfeng, S. Jianqiang, H. Guixiang and L. Weiping (2013). Probing the chiral separation mechanism and the absolute configuration of malathion, malaoxon and isomalathion enantiomers by chiral high performance liquid chromatography coupled with chiral detector-binding energycomputations. Journal of Chromatography A, 1281: $26-31$.

Barr, D.B. (2004). Concentrations of dialkyl phosphate metabolites of organophosphorus pesticides in the U.S. population, Environ. Health Perspect., 112: 186-200.

Borchert, M. (2001). Aussenwirtschaftslehre: Theorie und Politik, 7. Auflage, Wiesbaden: Gabler Verlag.

Hassan, A. and W.C. Dauterman (1968). Studies on the optically active isomers of O,Odiethyl malathion and O,O-diethyl malaoxon, Biochem. Pharmacol., 17: 1431-1439

Kaiser, S. A. K. M. and B. Saha (2005). Diseases of major fruit crops in the red and lateritic zones of West Bengal. Journal of Mycopathological Research, 43(2): 233-237.

Lehotay, S.J., M. Kaserina and A. R. Lightfield (2005). Use of buffering and means to improve results of problematic pesticides in a fast and easy method for residue analysis of fruits and vegetables. J. AOAC Int. 88 (2):615-629.

Lotfy, H. M., A. A. Abd El-Aziz and H.H Monir. (2013). Determination of insecticides malathion and lambada- cyhalothrin in zucchini by gas chromatography. Bulletin of faculty of pharmacy, Cairo University, 51: 255-260.

Penalver A., V. Garcı̌ı., E. Pocurull, F. Borrull, R.M. Marcé and P. Stir bar (2003). Sorptive extraction and large volume injection gas chromatography to determine a group of endocrine disrupters in water samples. J. Chromatogr. A, 1007: 1-9.

Ploetz, R. C. (2004). The major diseases of mango: strategies and potential for sustainable management. Acta Horticulturae. 645: 137-150.

Yu H.,X. Wang, H. Sun and M. Huo (2010). Photocatalytic degradation of malathion in aqueous solution using an $\mathrm{Au}-\mathrm{Pd}-\mathrm{TiO} 2$ nanotube film, J. Hazard. Mater., 184: 753-758.

Zhang A., L. Wenfeng, J. Sun, G. Hu and W. Liuc (2013). Probing the chiral separation mechanism and the absolute configuration of malathion, malaoxon and isomalathion enantiomers by chiral high performance liquid chromatography coupled with chiral detector-binding energy Computations J. Chromatogr. A, 1281: 26-31 


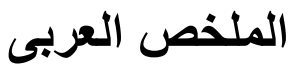

سلوك متبقيات مبيد الملاثيون و أحد مشتقاته الملاؤكسون فى أربع أصناف من ثمار المانجو

\author{
سناء عبد القادر الصاوى المئو \\ المعمل المركزى لتحليل متبقيات المبيدات و العناصر الثقيلة فى الأغذية
}

تم دراسـة معدل تحطم و تقدير متبقيات مبيد الملاثيون المستخدمة فى مكافحة الآفات الحشرية و أحد مشتقاته (الملاؤكسون) فى أربعة أنواع من ثمار المانجو (الفونس و الزبدية و

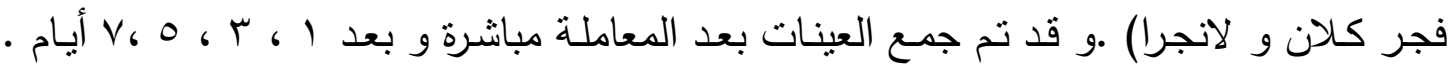
أظهرت النتائج أن معدل إسترجاع المركبات عالى و مقبول للطريقة المستخدمة فى التقدير حيث كان و و و 99\% للمالثيون و الملاؤكسون على التوالى. و قد تتاقص نركيز هذين المركبين بالتدريج و بعد خمس أيام تم الحصول على نتائج سلبية لمبيد الملاثيون نتيجة لتحطمه الكامل. و قد اتبع الملاؤكسون نفس السلوك حيث تم الحصول على نتائج سلبية بعد ب ايام من المعاملة. و قد تم حساب فترة نصف العمر لكلا المركبين و كانت ما بين جو ه. • الى ^.ب يوم للملاثيون و بـ . • الى 9 . •يوم للملاؤكسون و ذلك فى الأربعة أنواع من ثمار المانجو . تم أيضا حساب فترة الأمان قبل الحصاد لكل مبيد طبقا للحدود القصوى المسموح بها لكلا المركبين (الملاثيون و الملاؤكسون) و قد وجدت انها ب و ب أيام على التوالى • 